\title{
Dialogue and transformation: embracing sexual diversity in the educational context
}

\section{Diálogo e transformação: incluindo a diversidade sexual no contexto educacional}

\author{
Murilo dos Santos Moscheta ${ }^{1}$ \\ Sheila McNamee ${ }^{2}$ \\ Jucely Cardoso dos Santos ${ }^{3}$
}

\begin{abstract}
Although recent policies in education in Brazil have included sexuality as an important theme to be discussed in the classroom, it still has not effectively created an educational context where sexuality can be discussed in a positive, non-discriminatory and culturally/historically sensitive way. This article aims at contributing to the development of training programs for sexual educators, specifically for those who are concerned with the inclusion of non-normative sexualities in the educational context. Drawing on social constructionist ideas, we have delineated a model for a training program for sexual educators in which two themes - relational engagement and focus on the process - set the context for a transformation in education. First, we offer a brief review of sexual education in Brazil. Next, we introduce the notion of "intelligibility communities" and "dialogue," as useful concepts for exploring educational alternatives. These two concepts allow us to discuss how values are generated and how they play into our
\end{abstract}

1 Doutorando do programa de pós-graduação da Faculdade de Filosofia, Ciências e Letras de Ribeirão Preto (USP/SP) e co-coordenador do grupo VIDEVERSO grupo de ação e pesquisa em diversidade sexual.

2 Professor of the Department of Communication at the University of New Hampshire (UNH).

3 Psicóloga e co-cordenadora do grupo VIDEVERSO.

4 Agradecemos ao Prof. Dr. Manoel Antônio dos Santos pelas contribuição no desenvolvimento do grupo VIDEVERSO e pelas preciosas sugestões que favoreceram o desenvolvimento das atividades que ilustram este artigo. 
accounts about what we consider to be real and good. Finally, inspired by one of our training programs, we illustrate some ways in which these theoretical resources can be used in training activities.

Keywords: sexual education; gender and sexuality; teacher training; dialogue; social constructionism.

\section{RESUMO}

Embora as recentes políticas de educação no Brasil tenham incluído a sexualidade como tema importante a ser discutido nas salas de aula, elas ainda não efetivamente criaram um contexto educacional onde a sexualidade possa ser discutida de forma positiva, não-discriminatória e sensível as cultura e história do contexto. Este artigo tem como objetivo contribuir com o desenvolvimento de programas de treinamento para educadores em sexualidade, especificamente para àqueles preocupados com a inclusão de expressões sexuais não-normativas no contexto educacional. A partir de idéias construcionistas-sociais nós delineamos um modelo de treinamento para educadores em sexualidade no qual o envolvimento relacional e o foco no processo criam o contexto para uma educação transformadora. Primeiramente, apresentamos uma breve revisão da educação sexual no Brasil e posteriormente apresentamos os conceitos de comunidades de inteligibilidades e diálogo. Esses dois conceitos nos permitem discutir como os valores são gerados e como eles participam daquilo que tomamos como sendo bom e real. Por fim, inspirados por um de nossos programas de treinamento, nós ilustramos o modelo oferecendo possibilidades de tradução de princípios teóricos em atividades de treinamento.

Palavras-chave: educação sexual; gênero e sexualidade; formação docente; diálogo; construcionismo-social.

Education, within a post-modern perspective, is a revolutionary act. It is not the mere reproduction of established ideas or the inculcation of social norms. It is, rather, a generative process in which knowledge is constructed, not only achieved. It is a creative engagement in social transformation, not only understanding the world in which we live. Post-modern education attempts to create practices whereby people become authors of their stories, develop reciprocal relations with others and act for transformation (FREIRE, 1979). And, in a world of gender inequalities and sexual discrimination, this approach to education must also be an act of resistance. For Dinis (2008, p. 490): 
Um exercício de resistência exigiria ver-se de novos modos, dizer-se de novas maneiras, experimentar-se de novas formas, estranhar a imagem refletida no espelho que recorta nossas infinitas possibilidades, recusar toda miragem de identidade que nos torna limitados. Ensaiar formas curriculares que possam convidar à produção de novas formas de subjetividade, de novas estéticas da existência, desconstruir criativamente as fronteiras sexuais e de gênero.

Therefore, learning is something teachers create with their students, and in so doing, both students and teachers are transformed. In a world that seems dominated by traditional, modernist pedagogies, speaking about the teacher's transformation may sound radical and problematic. There is still some debate about the limits of public and private; about how much of a teacher's personal values are welcomed into the classroom. Additionally, there is controversy about pedagogical techniques that might depart from the traditionally valued "neutral and objective" approach to teaching (ROHDEN, 2009). In sexual education, fear of personal disclosure and the dominance of a discourse of tolerance make the neutral and apparently objective approach the standard attitude (JARDIM; BRÊTAS, 2006). Nevertheless, objective and biological approaches to sexuality tend to naturalize and essentialize culturally created forms of being, and tolerance contributes to the "status quo," not to its transformation. Both work for a dominant heteronormative system.

Thus, how can we conceptualize the transformation that is in process when teachers and students talk about sexuality? Is there a theoretical framework that could help us understand this process and thus, enable us to be consciously engaged in transformative educational practices?

This article is an attempt to answer these questions. We will first make a brief review of sexual education in Brazil to create the context of our discussion. Then, using the concepts of dialogue and "communities of intelligibility" we will present a model for understanding the educational process as a transformative one. Finally, we will discuss the resources for action that these concepts might inspire as they are used to design and develop training programs for sexual educators. We assume that a truly transformative sexual education takes place when a teacher is relationally engaged with his/her students. Additionally, we assume that such an education demands a problematization of the teacher's own values and taken for granted ideas about sexuality.

What we take as transformative education is informed by social constructionist (GERGEN, 2009; McNAMEE; GERGEN, 1998) ideas where learning is described as a relational achievement. Social constructionism is a generic 
term used to make reference to a broad array of theoretical perspectives that, in summary, share four basic assumptions: 1) knowledge produces what we take as reality, not only describes it; 2 ) this construction is contextually, historically and culturally dependant; 3 ) social practices maintain knowledge; 4) knowledge regulates social practices (BURR, 1995). From a social constructionist perspective, it is in relation with other people that we create, maintain and share meanings about the world.

Since meaning and knowledge are by-products of relations, neither can be merely conveyed from one mind to another. Therefore, education is conceptualized as a creative process in which educators and students engage in a relation that collaboratively produces meaning. This perspective is aligned with Paulo Freire's ideas and the distinction he makes between "banking" and problemsolving education (FREIRE, 2001).

One important implication of this perspective is that it requires that we replace our emphasis on individuals and their internal motivations, intentions and perceptions with an emphasis on the "coordinated" activities of people engaging with one another. The process of teaching, as well as the teaching relationship, takes center stage and attention to the content of what people do or say recedes as our major focus. Once knowledge is viewed as a collaborative construction, it is seen as a relational achievement, not a private, cognitive process. To the constructionist, abstract information cannot be transmitted or internalized. Rather, what we take to be "information" (i.e., knowledge and meaning construction) is socially, relationally accomplished as people coordinate actions to produce meaning that is deeply connected to their histories. Therefore, knowledge is not merely "accumulated" in the mind of an individual; it is generated in the constant embodiment of people relating to each other. Because this educational process transcends the cognitive engagement of its participants, we prefer to address it as a transformative, rather than a conscientzative process.

\section{Sexual education in Brazil}

Sexual education was formally included in school curricula in the 60's, although it was somehow present as an official educational concern before that time. In 1971, the Diretrizes e Bases da Educação Brasileira started to promote health programs in schools under which sexuality was discussed mostly to prevent teenage pregnancy and STDs. This health emphasis was stressed after 1992 as HIV prevention became one of the major public concerns and collec- 
tive efforts and policies to restrain the AIDs epidemic were organized (SILVA; NETO, 2006). At that time, sexuality was discussed in school contexts mostly with emphasis on its negative or potentially negative effects on students' lives; it was either something to be prevented or controlled. A more positive approach was implanted only at the end of the 90's with the publication of PCN - Parametros Curriculares Nacionais (SILVA; CARVALHO, 2005). In this document, sexual education is included as a transdisciplinary theme that must be discussed from three different perspectives: the body as the matrix of sexuality, gender relations, and AIDs/STD prevention. Although PCN represents an advance in terms of officially including and changing the tone of sex-related discussion in the classroom, it has been criticized for its lack of awareness to cultural and historical issues since sexuality is still defined as a biological and essentialized aspect of human life (ALTMAN, 2001).

This emphasis on the biological aspects of sexuality seems to be in accordance with teachers' experiences in the classroom. Without adequate training, teachers tend to reduce sexuality to biology in order to create an illusionary safe terrain where they can feel more comfortable speaking from a supposedly neutral and objective stance (BARCELOS, 1996; SILVA; CARVALHO, 2005). Thus, teachers tend to prefer to explain the physical changes during adolescence, as well as pregnancy and STD prevention, rather than discuss the cultural and historical aspects of sexuality (JARDIM; BRÊTAS, 2006). When an objective discussion is not enough and, for whatever reason, teachers are forced to go beyond the biological level, usually the discussion is poor and does not differ much from the dominant ideas that circulate in society and that are infused with social stigma and prejudice (SILVA; NETO, 2006). Difficulties seem to be greater when teachers try to address non-normative expressions of sexuality such as homosexuality and transexuality due to the predominance of crystalized and essentialized notions of identity in education (DINIS, 2006). Homosexuality is somehow rendered invisible in classroom discussions and the silence around non-normative sexualities reflects the lack of teachers' preparation. This invisibility also unveils the conservative and retrograde pedagogy that persists in school settings (FURLANI, 2007).

On the other hand, since the 60's social norms and values have been changing and the patriarchal social structure has been progressively eroded. Feminists have played an important role in changing the male-dominant structure that has produced so much of gender inequality. The AIDS epidemic motivated the organization of numerous gay, lesbian, bisexual and trangendered (LGBT) initiatives that brought sexual diversity into the discussion. By the turn of the century, mainstream media was populated with debates on gay marriage, and we followed stories of gay couples adopting children or fighting for their custody. In- 
timacy, relationships, family and identity have been all re-signified, and although hard to define, contemporary times have been described by plural, mutable and even liquid features (BAUMAN, 2010; GIDDENS, 1992; VAITSMAN, 1994). No matter how hard a school environment tries to ignore it, sexual diversity is persistently more and more present in students' lives: they may have gay friends or neighbors, they likely have been reading the newspapers, magazines or taking part in a 3-million-people gay pride parade, some are coming out as gay, lesbian or transgendered in school, some may have gay or lesbian parents, some have been ridiculed and bullied in the lunch-break or violently assaulted around the corner of the school, others may have been praised as "hip" and "trendy" by their peers. Teachers, who are usually from a different generation, seem to feel uncomfortable and underprepared to discuss these issues in the classroom.

Thus, although PCN has officially included sexuality as an important theme to be discussed in the classroom, it still hasn't effectively created an educational context where sexuality can be discussed in a positive, non-discriminatory and culturally/historically sensitive way. As PCN itself emphasizes, teachers should not be alone in this endeavor; they must be supported with lectures, group discussions, readings and supervision that would allow a greater understanding of their own values and limits, as well as, help them to develop an ethical attitude (SILVA; NETO, 2006).

How could teachers perform sexual education that is sensitive to the contemporary changes in social values? How could they do this without falling into the trap of a moralist and prescriptive sexual education? How could they avoid that trap without referring to calcified and pretentiously neutral biological models or sterile tolerance discourse? How could they develop an approach to sexual education that is sensitive, non-discriminatory and at the same time transformative?

As we stated above, it seems that the most common answer to these questions is often based on the assumption that personal values must be left outside the classroom and sexual education must be technologically focused. The usual result is sexual education that is centered on information dissemination that usually presents sexuality as detached from life. Educators and students are not invited to articulate their experiences and values. In this neutral and informative setting, conflict between possibly different rationales is minimized. But since sexuality has become dehumanized, personal growth and social change is also minimized.

Our experience in the collaborative research and design of training programs for educators in sexuality has led us to a different position. Informed by social construction (GERGEN, 2009; MCNAMEE; GERGEN, 1998), we adopt a relational understanding where sexual education is viewed as connected to 
the lives of educators and students, and thus, is not neutral. We share our view of education with Lave and Wenger (1991) who argue that learning should not be viewed as the transmission of information but as a process of constructing knowledge (and values) in community. Values are important for us because they play a key role in the construction and regulation of sexuality. We understand that despite the undeniable biological dimension of sexuality, its most important aspect is how it is described, narrated and organized within interactions that are always permeated by socially and culturally constructed values. Such understanding allows us to consider sexuality from the vantage point of its cultural and mutable meanings, avoiding essentialized (and static) approaches. Sexuality is socially, historically and contextually produced. This means that sexuality is not a stable and universal phenomenon that is simply presented or discussed in school settings. It is also produced there, in the interactions and descriptions that permeate the classroom relations. Thus, the very matter of sexual education (sexuality) cannot be properly addressed if its presentation neglects the elements involved in its production and regulation.

Therefore, in order to include communally constructed values in sexual education, educators have to develop a better understanding of the processes that generate, maintain and transform them. Values are themselves a historical and contextual by-product of human relations; they emerge from our interactions in the social world. In contemporary times, a myriad of different communities co-exist and generate different and often incommensurate values that, at the same time, are always intelligible within their communities of origin, or, as we refer to them, communities of intelligibility.

\section{Coordinating different intelligibilities and being relationally engaged}

With such a diversity of views about sexuality - each one sensible within its own context - education can only be achieved when the educator is able to recognize differing and sometimes incommensurate values and beliefs and when $\mathrm{s} / \mathrm{he}$ attempts to allow each to be voiced and respectfully heard. This requires educators to be relationally engaged and to appreciate the collaborative ways in which values and beliefs (meanings) are made.

The creation of values and beliefs emerges from a process of coordination. We might think, for example, of the first encounter between a teacher and a student. As the teacher enters the examination room, both student and teacher understand that the topic of conversation is focused on the student's academic 
abilities; the teacher questions and the student answers. From these coordinations, patterns and rituals quickly emerge (ritualization). Some teacher-student relationships might include questions that solicit a student's input on certain topics being discussed. The seasoned student might anticipate being asked for his/her input. These rituals generate a sense of standards and expectations that we use to assess our own and others' actions (standartization). Thus, if the teacher fails to ask about the student's ideas, the student might feel slighted or disrespected. Similarly, if the student fails to answer the teacher's questions, the teacher might feel that the expectations for the situation have been violated. Once these standardizing modes are in place, we see the generation of more global values and beliefs (i.e., social realities). That is, we are left with an unquestioned set of assumptions about, in this case, "how a classroom encounter should go." Beliefs and values are, in their turn, the basis from which new coordinations can emerge. This process is illustrated in the diagram below.

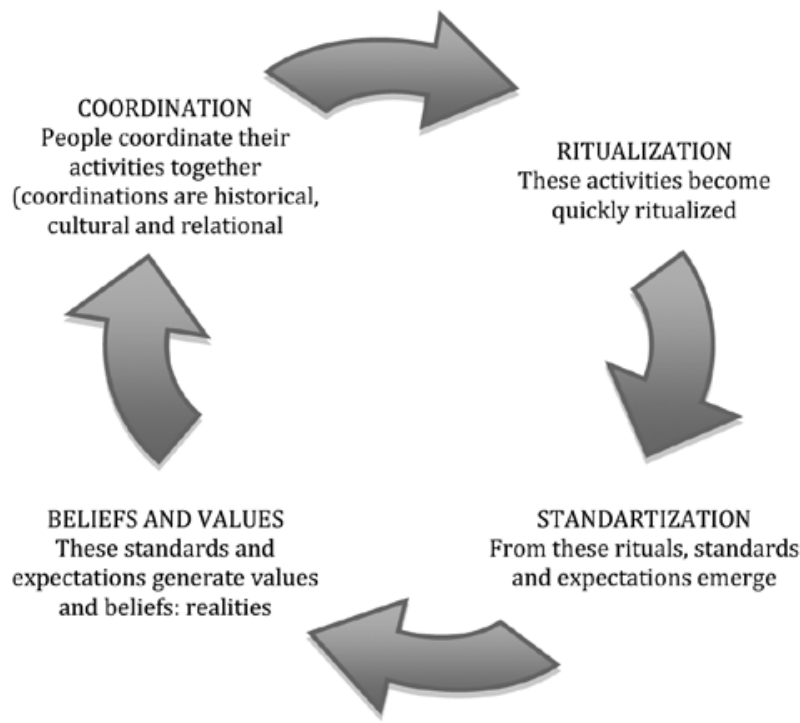

We use this model to think about the production and reproduction of values around the performances of masculinity and femininity among students. Imagine, for example, a female student who is ridiculed by her peers for being overly sexual. Her gender performance breaks the expectation that this community has generated about how a girl must behave, and it is only by the standards of this intelligibility that she can be assessed as overly sexual. We 
could say that this group of students coordinate their actions as boys and girls so that their performances of masculinity and femininity become ritualized. As the rituals become standardized, this group of students expects every other student to perform as they do. Their coordinated performances become values that represent how someone should behave. The so-called "overly sexual" girl is someone who coordinates her gender performance in a different community, thus she doesn't act in accordance to the other students' expectations. She may come from a community (a previous school, her neighborhood or family) where her performance is not overly sexual, or where being overly sexual is a valuable, and not demeaning, characteristic.

Another example would be the compulsory assumption that every student (and teacher) is heterosexual. This assumption represents the expectation that students and teachers are heterosexuals. And where does this expectation come from? It comes from previous group coordinations (from small groups like families to broader ones like society and media discourse) that define that a man is attracted to women and vice versa. And what are the effects of this expectation? It generates values and beliefs that this is the way people must be, thereby creating the context for coordinations that will reproduce the values that are in its matrix (as the circle in the diagram feeds into itself). Because heterosexuality is taken for granted, most often, images of gay or lesbian couples are not present in books at school. Conversations, examples and jokes are made with the presumption (expectation) that everyone in the classroom is heterosexual. Quickly the notion that everyone in the room must be heterosexual (a value) is established and the idea that being different is abnormal or wrong quickly follows.

Understanding the contextual and relational matrix of values enables the educator to embrace sexual education in a sensitive and human way. The educator can acknowledge his/her values as well as the students' values as coherent within different relational contexts. The task that emerges is not one of producing a consensus of values, either by persuasion, imposition or discipline, but one of exploring the diversity. Diversity, encountered within a dialogic context, creates fertile ground for growth and change. And, dialogue requires relational engagement.

The use we make here of the word dialogue is a very particular one. First, we understand that dialogue is a responsive activity (BAKHTIN, 1982). It is focused on the process of communication, on how people are talking (and acting) "in response" to each other, and how their responses are mutually influenced by each other.

Second, dialogue acknowledges the different values and beliefs people bring to the conversation (PENMAN, 2000). In this sense, dialogue is radically different from debate, where communication is aimed at persuading the other or 
at defending a set of beliefs. In dialogue, ideas are presented in the context of lived experiences. There is an attempt to avoid speaking from abstract positions (i.e., "this is wrong" or "this is good") and, instead, there is an effort to let the participants make sense of the different communities of intelligibility from which they originate. Instead of attacking or defending ideas, participants are curiously engaged in creating meaning. Thus, dialogue is marked by openness to diverse understandings that are the by-product of coordination among participants (note the earlier diagram).

Third, dialogue is an ongoing and unfolding process in the sense that the meaning that emerges from it is constantly changing and doesn't have a pre-determined goal. In other words, dialogue is not focused on any particular technique or content. Finally, no meaning, no conversation is ever ultimately complete. Meaning that emerges within an interaction is always open to further supplementation and thus to the construction of new understandings.

Julia Wood (2003), drawing on the work of Bakhtin (1982), emphasizes that responsiveness is the key feature of dialogical interaction. For her, responsiveness "arises out of and is made possible by qualities of thought and talk that allow transformation in how one understands the self, others, and the world they inhabit" (p. xvi). If we are responsive to others - particularly to others who have views that are incommensurate to our own - then we are open to critical reflection of our own commitments and beliefs. The incommensurate worldviews at play might best be cast as the subtle opposition between "right" and "wrong" notions of sexual identity.

Therefore, a dialogic approach to sexual education requires that we shift focus from the content of what people are doing and saying (i.e., the delivery of neutral information about essentialized sexuality) to the processes in which they engage and how their actions invite each other into particular rituals and relationships (i.e., the exploration of how varying values and beliefs about sexuality have emerged). This is not to say that content does not matter; of course it does - particularly in the world of public policy and education. However, the dialogic focus we are proposing here encourages a "pause" if you will, in our attention to content. When we emphasize process, not content, we try to be attentive to the ways in which we might build conversational domains where people can talk in different ways about the same (old) issues.

This means that our first task is to explore ways of creating a context (physical, relational, and personal) that invites participants to talk differently about a topic, in this case, sexuality. We believe that the concepts of communities of intelligibility and dialogue, as formulated above, can help us develop a model of sexual education where values do not need to be denied or oppressed. They can be acknowledged as part of human interaction and then, as they are dialogically 
articulated, the possibilities for considering more complex understandings of sexuality can unfold. In other words, we believe that a dialogic approach in sexual education can generate a more respectful and appreciative context; a context that allows diverse views of sexuality to comingle.

\section{Resources in action}

The concepts of communities of inteligibilities and dialogue have informed our work with groups and teams in different contexts. The resources they offer for the development of more inclusive practices toward LGBT clients in the health field has been discussed in Moscheta and Santos (2010) and Moscheta, McNamee and Santos (2010). In this paper we want to discuss the contributions of these concepts in designing and developing training programs for educators that could promote inclusive practices toward LGBT people in the educational context. For that, we will present a series of activities we used in one of our projects to illustrate how these concepts informed our work. It is not our aim to offer a detailed presentation of the project, and an evaluation of its results is beyond the scope of this paper. The program is presented here to illustrate the theory and how we have embraced the challenge of translating it into a practice. We hope this discussion inspires the reader to embrace this challenge as well. We also present a table that summarizes the principles we took into account to organize the design of our program and offer a list of questions that may be useful to consider when designing educational programs in this model (table 2).

The activities we will present were part of a project that started when the Municipal Secretary of Education of a small town of São Paulo state invited us to design and implement a short-term training program on sexuality for educators. The proposal defined that all educators from the elementary and intermediate level schools would be invited for a 10 hour program. The program would be offered during the educators' work time but participation was voluntary. The expectation was that the program would cover broad issues in sexuality, with special attention to homophobia and non-normative sexuality.

Our aim, as we designed this training program, was to have educators engaged in a reflexive process where they could simultaneously access, reflect and amplify meanings they have constructed regarding sexuality. Assessment, reflection and change are not separate processes, since the latter is an inevitable component of dialogic interactions, as we conceptualized them. For us, as we have already stated, the resources for working with sexuality are developed when 
the educators engage in the exploration of their own values and move forward in the understanding of the relativity of their construction. When educators are able to see their values as contextual constructions, they became better able to entertain values that are incommensurate by their own intelligibilities, and thus, they can respond in a more flexible and sensitive way - that is, beyond the discourse of "right and wrong."

The program consisted of a two-hour conference with optional participation in two four-hour workshops. Fifty educators attended the conference, which was planned to motivate their participation in the workshops. The conference presented sexuality as an historical and contextual product and was designed to appeal to educators' memories and personal histories. It ended with a synthesis of the challenges educators face in dealing with sexuality in the school context and with an invitation to continue the discussion in the two following workshop meetings.

Among the fifty educators who attended the conference, forty (divided in two groups of twenty) decided to participate in the workshops. Workshops were offered at two different times to accommodate educators with different work schedules.

Three thematic axes organized the workshop activities. The first one was designed to stimulate a conversation on the participants' perceptions about sexuality and how it had been constructed within their personal histories. The main goal in this group of activities was to generate a broader understanding of how each person's view about sexuality is formed within his or her history and within his or her unique network of relationships. Personal stories about how the teachers were educated regarding sexuality were stimulated in an effort to increase the awareness about the moral values that regulate sexual expression in society.

The first activity we proposed in the workshop aimed to invite the educators into dialogue. In order to prepare them to engage in this difficult task, we asked them to first write their concerns and questions about sexual education on colored paper. The colored paper was indicative of the level of difficulty they experience talking about these concerns and questions (little/green, some/ yellow, and a lot/red). This allowed us to discuss the concerns and questions anonymously. This discussion was followed by an activity where, in small groups, using different graphic resources, the group was asked to produce a collage that expressed their perceptions towards sexuality.

These two activities emerged from our understanding that when people gather for a dialogue, they come from a particular position or network of relationships that contribute to their thoughts, feelings and meanings toward sexuality (BECKER et al., 1996). So, if participants want to make sense to 
each other, they need to speak to those positions. The activities were planned to help us gauge how to be responsive to participants' needs and create a safe context for dialogue. Second, these activities invited the participants to present their questions and concerns, and afterwards organize them within a framework that expressed they perceptions towards sexuality. We wanted them to do that because we assume that it can offer the group the possibility of accessing the communities of intelligibility from which they come. In doing that, participants become contextualized; they offer stories that render a rationale for the construction of their values. By opening the workshop in this manner, we were trying to create a context where speaking from abstract positions (i.e., "It's wrong to be homosexual!") and engaging in the debate that usually emerges from these abstractions was avoided. Ideas are debatable, they easily create polarizations (right/wrong, good/bad) and foster a conversation organized to persuade or defend (MCNAMEE, 2007a; SAMPSON, 2008; STEWARD; ZEDIKER, 2002). Instead of ideas, we invited the participants to share their stories and we stimulated them to be curious about both their own stories and the stories of others. Thus, in both activities we didn't attempt to answer their original questions, but created a context for the group to explore the questions and to create connections with their experiences inside and outside the classroom.

We believe that there is an important difference between opening the workshop asking for their questions and, for example, opening the workshop asking for opinions on a specific issue. Once we are focused on the relational process, we are concerned with the different effects that our questions can produce. Specifically, when we ask for their questions, we invite them to look for what they want to know. On the contrary, when we ask for their opinions, we invite them to look for what they already know. If questions can create space for curiosity and the creation of a collective search, opinions can easily be presented as isolated perspectives that must be scrutinized or defended.

These activities have the potential to generate a complex description of sexuality that is contextually and historically situated once it is based in personal histories. Participants can see how their stories help to create what they take as sexuality. And because the activity is in a group, they can also see the variety of understandings about the same issue. Second, they can favor a greater understanding of the process by which values around sexuality are generated. And third, they invite participants to reflect about how their own values and sexual education inform their performances as sex educators.

The second thematic axis focused on giving some information about the different components of sexuality, how sexuality is categorized in social discourse and how these discourses operate in order to stimulate or discriminate different expressions of sexuality. 
The previous activities were designed to generate the context in which participants could see themselves as part of an historical and social process. We believe that this historical perspective creates the conditions within which to discuss sexual identity categories as contextual. Therefore, in our next activity, we invited participants to try to define sexuality and we stimulated them to think about its different dimensions such as body, emotions, gender roles, desires and sexual identity.

When the discussion about sexual identity categories is preceded by an appreciation of how sexuality and values are historically dependent it is easier to foster a discussion in which sexual identity categories can be understood as artificial productions. Essentialist and naturalized views on sexuality can be more easily deconstructed as the social and historical production of categories becomes evident. Usually, the following step in this deconstruction of sexual identities is the reflection about the arbitrary prioritization of one category over the others and the resultant oppression and stigma. When educators become familiar with these categories as social productions, they also are able to see these categories as strategic descriptions, as Foucault (1979) would say, for social transformation.

As we have learned, the power of dialogue resides in its potential to generate new descriptions about experiences that have been repeatedly described in the same way. When those saturated descriptions change, a new venue for understanding is opened and new relations and resources can emerge (MCNAMEE, 2007b; MCNAMEE; GERGEN, 1998). One way of promoting such transformation is to invite people to talk about a situation that evokes less intense emotions and that is less saturated by values and judgments. That was our goal when we invited the participants to engage in an activity where they had to identify a favorite season as they listened to The Four Seasons by Vivaldi. We generated a context where they could talk about their preferences, how they identified them, what they thought contributed to that preference, among other things. Then, we asked the group to discuss sexual identities using the ideas generated by the reflection on their season preference. The use of a metaphor (the season in this case) can help the participants to discuss sexual identities in terms of their preferences emphasizing how those preferences were a by-product of multiple determinants and how they have fluid and inter-dependent qualities, thereby avoiding the reproduction of an hierarchy of sexuality. The metaphor of the four seasons offers a positive model to approach difference, where preferences do not need to be evaluated (as right or wrong, normal or abnormal) but can be appreciated as a diversity that enriches our experience in the world.

From this point, we could move to more pragmatic concerns, which compose the third axis of our program. In the next two activities we presented the legal 
regulations and guidelines for work with sexual diversity in school as defined in the Parâmetros Curriculares Nacionas (PCN). Since the previous activities had focused on creating a dialogic context, we were able to stimulate participants to actually relate to the information, raising dilemmas and engaging in a critical and creative reflexive exercise. Without the dialogic context in which information can be personally and historically related, the presentation of guidelines would unlikely be critically received. This is the fundamental difference that defines education as a conjoint creative and transformative process: the creation of relatedness between one's history and any given information.

Finally, we divided the group in two sub-groups and asked them to roleplay two different problematic situations they could draw from their experience as educators. They were challenged to create different endings for these dilemmas. Again here, we aimed at producing a complex and multidimentional understanding of sexuality that would not allow single and standardized responses. The participants were invited to produce responses that were sensitive to the different rationales involved in the situation and at the same time they were stimulated to think of them not as the right answer or solution, but as possible responses with particular implications. It seems to us that one advantage of the relational and process-focused approach that informs our activities is the possibility of the approach, itself, to become a resource for educators; the approach could be used to evaluate educators' responses to students, for example. The relational focus allows the educator to think about their responses to students no longer as limited to content (good/bad, right/wrong) and invites them, instead, to consider the pragmatic implications of different perspectives.

\section{New ways forward}

This article is an attempt to articulate a conceptual orientation (social construction and dialogic process) to education and specifically, in preparing educators to work with sexuality. It is beyond the scope of this article to discuss the results and effectiveness of the program we implemented.

It is very important to highlight that we are not presenting a technique. We consider technique a pre-defined strategy that is applied in a context and/or situation. Once it is pre-defined it cannot be responsive to the participants in the interactive moment. Furthermore, we agree with Paulo Freire's critique about the use of pedagogical techniques as a way of reducing and dehumanizing relations (FREIRE, 1979). What we are offering here is a model that we define as a set 
of "resources for action" that might be taken as an inspiration. These resources are constantly put to use in response to contextual and relational demands which means that we are never doing exactly the same thing when we draw upon a particular resource. This difference is very important for what we have been presenting here is, above all, an effort to articulate an educational model that is focused on the process and not the content of education and learning.

We believe that education about sexual diversity must move beyond the essentialized discourse of biology and the unquestioned presumption that heterosexuality is the norm. In order to make such a move, an understanding of how values and beliefs - that serve as the impetus for action in the world - must be explored and one way to explore the construction of values and beliefs is to create contexts where communities of intelligibility can be explored dialogically. We hope that the ideas we presented here can inspire other studies and training programs engaged in embracing diversity and promoting sexual education that is inclusive and transformative.

\section{REFERENCES}

ALTMAN, H. Orientação sexual nos Parâmetros Curriculares Nacionais. Revista Estudos Feministas, v. 2, n. 9, p. 575-585, 2001.

BAKHTIN, M. The Dialogic Imagination: Four Essays. Texas: University of Texas Press, 1982.

BARCELOS, N. S. Educação sexual: relato de uma experiência. Revista Brasileira de Sexualidade Humana, v. 7, p. 150-160, 1996.

BAUMAN, Z. Liquid Times: Living in an Age of Uncertainty. Cambridge: Polity, 2010.

BECKER, C.; CHASIN, L.; CHASIN, R.; et al. From debate to dialogue: a facilitating role for family therapists in the public forum. Mediation Quaterly, v. 13, n. 2, p. 323344, 1996.

BURR, V. An Introduction to Social Constructionism. New York: Routledge, 1995.

DINIS, N. Educação, cidadania e as minorias sexuais e de gênero. In: SCHIMIDT STOLTZ, M. A. (Eds.). Educação, cidadania e inclusão social. Curitiba: Aos Quatro Ventos, 2006. p. 131-135.

. Educação, relações de gênero e diversidade sexual. Educação e Sociedade, 
v. 29, n. 103, p. 477-492, 2008.

FOUCAULT, M. Microfísica do poder. 1st ed. Rio de Janeiro: Graal, 1979.

FREIRE, P. Educação e Mudança. 28. ed. São Paulo: Paz e Terra, 1979.

. Concientização: Teoria e Prática da Liberdade. 3rd ed. São Paulo: Centauro, 2001.

FURLANI, J. Sexos, sexualidades e gêneros: monstruosidades no currículo da Educação Sexual. Educação em Revista, v. 46, p. 269-285, 2007.

GERGEN, K. An invitation to social construction. 2nd ed. Los Angeles: Sage Publications, 2009.

GIDDENS, A. The Transformation of Intimacy: Sexuality, Love, and Eroticism in Modern Societies. 1st ed. Cambridge: Polity, 1992.

JARDIM, D. P.; BRÊTAS, J. R. D. S. Orientação sexual na escola: a concepção dos professores de Jandira - SP. Revista Brasileira de Enfermagem, v. 59, n. 2, p. $157-$ 162, 2006.

LAVE, J.; WENGER, E. Situated Learning. Legitimate peripheral participation, Cambridge: University of Cambridge Press, 1991.

MCNAMEE, S. Transformative Dialogue: Coordinating conflicting moralities. . Retrieved from http://www.unh.edu/liberal-arts/faculty/lindberg_2007.html, 2007a.

. Relational practices in education: Teaching as conversation. In: H. ANDERSON, H.; GEHART, D. (Eds.). Collaborative Therapy: Relationships and Conversations tha Make a Difference. London: Brunner-Routledge, 2007b. p. 313-335.

MCNAMEE, S.; GERGEN, K. Relational responsibility: resources for sustainable dialogue. Thousand Oaks Calif.: Sage, 1998.

MOSCHETA, M. S.; MCNAMEE, S.; SANTOS, M. A. Responsiveness in Health Qualitative Research: Resources for Inquiry and the Development of Non-discriminatory Healthcare Assistance. In: Anais... . Urbana-Champaign, Illinois, USA, 2010.

MOSCHETA, M. S.; SANTOS, M. A. Inclusão e o desafio de criar formas de investigação colaborativas - um relato de experiência. Saúde e Transformação Social, v. 1, n. 1, p. 154-159, 2010.

PENMAN, R. Reconstructing Communication: Looking To A Future. Mahwah: Erlbaum, 2000.

ROHDEN, F. Gênero, sexualidade e raça/etnia: desafios transversais na formação do 
professor. Cadernos de Pesquisa, v. 39, n. 136, p. 157-174, 2009.

SAMPSON, E. Celebrating the other: a dialogic account of human nature. Chagrin Falls OH: Taos Institute Publications, 2008.

SILVA, M. P.; CARVALHO, W. L. P. O desenvolvimento do conhecimento pedagógico do conteúdo de sexualidade na vivência das professoras. Ciência \& Educação, v. 11, n. 1, p. 73-82, 2005.

SILVA, R. C. P.; NETO, J. M. Formação de professores e educadores para abordagem da educação sexual na escola: o que mostram as pesquisas. Ciência \& Educação, v. 12, n. 2, p. 185-197, 2006.

STEWARD, J.; ZEDIKER, K. Dialogue as tensional, ethical practice. Southern Communication Journal, v. 65, n. 2/3, p. 224-242, 2002.

VAITSMAN, J. Flexiveis e plurais: Identidade, casamento e familia em circunstancias pos-modernas (Genero plural). São Paulo: Rocco, 1994.

WOOD, J. Foreword: Entering into dialogue. In: ANDERSON, P. R.; BAXTER, L. A.; CISSNA, K. N. (Eds.). Dialogue: Theorizing Difference in Communication Studies. Sage Publications, Inc, 2003. p. 15-23.

Texto recebido em junho de 2010.

Texto aprovado em outubro de 2010. 
TABLE 1 - DESCRIPTION OF THE ACTIVITIES AND THEIRS OBJECTIVES, USED IN THE TRAINING PROGRAM IN SEXUAL EDUCATION

\begin{tabular}{|c|c|c|}
\hline activity & Description & objectives \\
\hline Traffic light & $\begin{array}{l}\text { Participants were asked to write their questions and } \\
\text { concerns regarding sexuality in colored papers. Green } \\
\text { was the color for the easiest themes, yellow and red } \\
\text { for the medium and very difficult ones, respectively. }\end{array}$ & $\begin{array}{l}\text { Access in which direction the workshop } \\
\text { should go; } \\
\text { b) Start generating a complex image of } \\
\text { the theme; } \\
\text { c) Create a context where participants could } \\
\text { be motivated and personally engaged. }\end{array}$ \\
\hline Collage & $\begin{array}{l}\text { Divided in groups of } 4 \text {, participants had to create } \\
\text { a panel about sexuality with magazine clippings, } \\
\text { colored pens and chalks. Each small group had the } \\
\text { opportunity to present their panel to the other groups } \\
\text { explaining what they tried to express on it. }\end{array}$ & $\begin{array}{l}\text { Create a context for personal presentation } \\
\text { about participant's values and beliefs } \\
\text { regarding sexuality; } \\
\text { b) Stimulate a conversation where } \\
\text { the social, cultural and historical } \\
\text { determinants of sexuality and values } \\
\text { could be considered. }\end{array}$ \\
\hline $\begin{array}{l}\text { What is } \\
\text { sexuality? }\end{array}$ & $\begin{array}{l}\text { Participants were stimulated to discuss and try to } \\
\text { generate a definition for sexuality. Coordinators mo- } \\
\text { tivated the participants to think about biological and } \\
\text { psychological determinants, gender roles and gender } \\
\text { performances, desire and sexual identity. }\end{array}$ & $\begin{array}{l}\text { Generate a multidimensional and context sensi- } \\
\text { tive understanding about sexuality and } \\
\text { challenge the essentialized and natural- } \\
\text { ized descriptions. }\end{array}$ \\
\hline Four seasons & $\begin{array}{l}\text { At the sound of Vivaldi's Four Seasons concert, the } \\
\text { participants had to walk around the room as they } \\
\text { tried to identify what was their favorite part of the } \\
\text { concert. Afterwards they get together in small groups } \\
\text { according to their favorite season and discussed why } \\
\text { they felt more attracted to it. The discussion was then } \\
\text { presented to the whole group and connections were } \\
\text { made with sexual preferences. }\end{array}$ & $\begin{array}{l}\text { a) generate a conversation about sexual } \\
\text { identity categories that is not saturated } \\
\text { by the traditional values associated with } \\
\text { them. } \\
\text { b) Allow the participants to experience a } \\
\text { model that would help them to consider } \\
\text { the complexity of sexual identities and } \\
\text { avoid the traditional hierarchization of } \\
\text { categories. } \\
\text { c) Create a context for a conversation where } \\
\text { diversity is appreciated and not judged. }\end{array}$ \\
\hline $\begin{array}{r}\text { Talking about } \\
\text { discrimination }\end{array}$ & $\begin{array}{l}\text { Participants were introduced to the legal regulations } \\
\text { that protect people from sexual orientation and gender } \\
\text { discrimination and invited to discuss them. }\end{array}$ & $\begin{array}{l}\text { Encouraged participants to develop non- } \\
\text { discriminatory and protective educational } \\
\text { practices as well as insert them within a } \\
\text { broader cultural, social and legal context. }\end{array}$ \\
\hline $\begin{array}{l}\text { Video: "Pra } \\
\text { que time ele } \\
\text { joga?" }\end{array}$ & $\begin{array}{l}\text { The video was produced by Ministério da Saúde e } \\
\text { Coordenação Nacional dst/aids in } 2002 \text {, and was } \\
\text { focused on sexual diversity in school. After the video } \\
\text { presentation, participants were encouraged to share } \\
\text { their own experiences as teachers examples from their } \\
\text { practice were discussed. }\end{array}$ & $\begin{array}{l}\text { Discuss sexual diversity in school and articulate } \\
\text { it with teachers experiences and stories. }\end{array}$ \\
\hline Role-playing & $\begin{array}{l}\text { Divided in two sub-groups, participants were invited } \\
\text { to role-play two dilemmatic situations they lived at } \\
\text { work. Then, the groups were challenged to create } \\
\text { possible endings for the story based on what they } \\
\text { had discussed and learned during the workshops. }\end{array}$ & $\begin{array}{l}\text { P) Produce a complex and multidimensional } \\
\text { understanding of sexuality; } \\
\text { Have the participants engaged in } \\
\text { producing responses that were sensitive } \\
\text { to different rationales. } \\
\text { c) Stimulate a process-oriented responses. }\end{array}$ \\
\hline
\end{tabular}


TABLE 2 -AXIS, PRINCIPLES AND QUESTIONS THAT CAN BE USED TO ORGANIZE THE DESIGN OF DIALOGIC TRAINING PROGAMS FOR SEXUAL EDUCATORS

\begin{tabular}{|c|c|c|}
\hline Axis & Principles & Questions to be considered \\
\hline $\begin{array}{l}\text { Creating } \\
\text { the con- } \\
\text { text for } \\
\text { dialogue }\end{array}$ & $\begin{array}{l}\text { - Dialogue is not a debate } \\
\text { - Stories are more relevant } \\
\text { than opinions } \\
\text { - Acknowledge and access } \\
\text { different communities of } \\
\text { intelligibility from which } \\
\text { people come }\end{array}$ & $\begin{array}{l}\text { Do the physical and material conditions } \\
\text { of the space allow us to have a safe, } \\
\text { comfortable and welcoming ambiance? } \\
\text { Does the invitation for dialogue generate } \\
\text { an appreciation for what participants may } \\
\text { contribute? } \\
\text { Does the opening activity invite } \\
\text { participants to be fully (not only } \\
\text { cognitively) engaged in the conversation? } \\
\text { Does the activity invite people to tell their } \\
\text { stories rather than give their opinions? } \\
\text { Does the activity allow the participants } \\
\text { to access the different context and } \\
\text { communities from which they come? }\end{array}$ \\
\hline $\begin{array}{c}\text { Sexuality: } \\
\text { in search } \\
\text { of a defi- } \\
\text { nition }\end{array}$ & $\begin{array}{l}\text { - Appreciation for difference } \\
\text { - Curiosity and exploration } \\
\text { instead of definite } \\
\text { explanation } \\
\text { - Search for new and non- } \\
\text { saturated possibilities of } \\
\text { talking }\end{array}$ & $\begin{array}{l}\text { Does the activity allow us to talk } \\
\text { about sexuality as social and historical } \\
\text { productions? } \\
\text { Does the activity invite participants to } \\
\text { critically consider the effects of sexual } \\
\text { identity categorization? } \\
\text { - Does the activity stimulate participants } \\
\text { to generate new metaphors to talk about } \\
\text { sexuality? } \\
\text { Does the metaphor foster the generation of } \\
\text { new ways of talking about sexuality? } \\
\text { Does the activity favor an appreciative } \\
\text { stance toward difference? Does it avoid } \\
\text { judgment and evaluation? }\end{array}$ \\
\hline $\begin{array}{l}\text { Pragmatic } \\
\text { concerns }\end{array}$ & $\begin{array}{l}\text { - Information must be } \\
\text { contextually translated } \\
\text { - Exploration of possibilities } \\
\text { rather than definition of } \\
\text { right/wrong } \\
\text { - Attention to the effects and } \\
\text { repercussions }\end{array}$ & $\begin{array}{l}\text { Does the activity present information in } \\
\text { a way that stimulates reflexive thinking, } \\
\text { personal engagement and contextual } \\
\text { articulation? } \\
\text { Does the activity create relatedness } \\
\text { between educators' stories and the } \\
\text { presented information? } \\
\text { Does the activity allow participants to } \\
\text { think about their responses as possibilities } \\
\text { instead of right or wrong? } \\
\text { Does the activity invite participants } \\
\text { to consider the implications of their } \\
\text { responses rather than the truth they may } \\
\text { express? }\end{array}$ \\
\hline
\end{tabular}

